\title{
Metered Gel Dosage Form
}

National Cancer Institute

\section{Source}

National Cancer Institute. Metered Gel Dosage Form. NCI Thesaurus. Code C60930.

A gel contained in a device with valves that permits the release of a uniform dose of gel

that composed of active and/or inert ing redient(s) upon activation. 